\title{
$\mathrm{Al}-\mathrm{Si}$ 二元合金の電気比抵抗と熱伝導率に対するケイ素含有量の影響
}

\section{岩崎 祐紀}

Journal of The Japan Institute of Light Metals, Vol. 72, No. 1 (2022), 22-26

(C) 2022 The Japan Institute of Light Metals

\section{Effects of silicon content on electrical resistivity and thermal conductivity of Al-Si binary alloys.}

\author{
Yuki IWASAKI
}

\begin{abstract}
Thermal conductivity is useful to improve performance and manufacturing process for various products. In this study, thermal conductivity was measured for solution-treated Al-Si alloys, and the influence of solute Si on thermal conductivity was studied. For quantification of metallurgical structure, electrical resistivity was measured. Ingots of Al-Si alloys were prepared with Si content between 0.5 and $10 \mathrm{mass} \%$. Thermal conductivity was measured at room temperature $(294 \sim 300 \mathrm{~K}), \lambda$, after heat treatment at $843 \mathrm{~K}$ showed a good proportional relation to Si content up to $1.4 \%$. The specimens of Si content above $5 \%$ showed negative deviations from the proportional relation, suggesting incomplete dissolution of silicon. Contribution per unit concentration of solute Si to the $\lambda^{-1}$ was $0.856 \times 10^{-3} \mathrm{~W}^{-1} \mathrm{~m}$ - $\mathrm{K} \cdot \mathrm{mass}^{-1}$. Electrical resistivity was measured at room temperature $(298 \mathrm{~K})$ and $77 \mathrm{~K}$. Electrical resistivity also showed a good proportional relation to Si content up to $1.4 \%$. Contributions per unit concentration of solute Si to the resistivity at $77 \mathrm{~K}$ and at $298 \mathrm{~K}$ were $5.65 \mathrm{n} \Omega \mathrm{m} \cdot \mathrm{mass}^{-1}{ }^{-1}$ and $5.71 \mathrm{n} \Omega \mathrm{m} \cdot \mathrm{mass} \%{ }^{-1}$, respectively. For specimens of Si content above 5\%, volume fractions of Si particles were calculated from the measured values of thermal conductivity and electrical resistivity, respectively. Both of volume fractions were larger than calculated value from the concentration of solute Si.
\end{abstract}

(Received October 8, 2021 Accepted November 1, 2021)

Keywords: Al-Si alloy; thermal conductivity; electrical resistivity; solute concentration dependence; volume fraction

\section{1. 緒言}

熱伝導率や比熱といった熱物性は様々な製品の機能の指 標，および製造工程の改善に活用されている。重力鋳造やダ イキャストといった鋳造は金属材料の主要な製造方法であ り，鋳物の性能向上や鋳造欠陷低減を目的とした開発が進め られている。鋳型設計や鋳造方案策定のため, 対象金属ある いは合金の複数の物性值がシミュレーションに使われてい $3^{1), 2)}$ 。例えば自動車では, エンジン等の主要部品にアルミ ニウム合金鋳物が多く採用されており，その熱効率向上のた めに熱伝導率などの熱物性值が設計に必要とされているが, アルミニウム合金では測定データがあまり公表されていな い。 $\mathrm{Al}-\mathrm{Si}$ 二元合金については, 電気比抵抗の測定データは公 表されている3 が, 熱伝導率の測定事例は少ない。Si 添加量 を最大 60 mass\% とした Al-Si 合金の Si 添加量依存性の報告が あるものの, 0 mass\%の次は 12 mass\%であり，一般的な鋳造 合金の添加量である3〜10 mass\%のデー夕は無い ${ }^{4)}$ 。電気比 抵抗と熱伝導率の両方を評価した研究については，電気比抵 抗を測定してヴィーデマン・フランツ則から熱伝導率を算出 したという報告がある ${ }^{5)}$ が，両方を実測した報告は見当たら
ない。

本報では，鋳造用アルミニウム合金の主要な合金系である Al-Si合金6)について熱伝導率と電気比抵抗を測定し, それぞ れに対する $\mathrm{Si}$ 固溶量の影響を調査し, 晶析出 $\mathrm{Si}$ 粒子の体積分 率の推定を試みたのでその結果を報告する。

\section{2. 実験方法}

\section{1 供試材}

供試材は Si 添加量を 0.5〜 10 mass\%（以後は mass\%を\%と 表記）の5水準としたAl-Si二元合金である。合金組成を Table 1 に示す。鋳造は 99.7\%Al地金を使用し, 鋳込重量約 $1 \mathrm{~kg}$ の舟 型インゴットを作製した。作製したインゴットから所定形状 に加工した試験片を大気炉にて $843 \mathrm{~K} て ゙ 14.4 \mathrm{ks}$ 保持後, 水水 中に焼入れして溶体化処理した。溶体化処理温度は, Murray $ら^{7)}$ が整理した状態図から得られた $\mathrm{Al}-\mathrm{Si}$ 二元系の平衡固溶度 の式

$$
C^{\mathrm{Si}} / \mathrm{mass} \%=2034 \exp (-6053 / T)
$$

より $\mathrm{Al}-1.4 \% \mathrm{Si}$ 合金での $\mathrm{Si}$ の完全固溶温度を $831 \mathrm{~K}$ と推定し, 完全固溶温度より約 $10 \mathrm{~K}$ 高い $843 \mathrm{~K}$ とした。 
Table 1 Chemical compositions of the investigated specimens.

\begin{tabular}{c|c|c|c|c|c|c|c|c}
\hline \hline \multirow{2}{*}{ Specimen } & \multicolumn{7}{|c}{ Analyzed composition / mass \% } \\
\cline { 2 - 9 } & $\mathrm{Si}$ & $\mathrm{Fe}$ & $\mathrm{Cu}$ & $\mathrm{Mn}$ & $\mathrm{Mg}$ & $\mathrm{Cr}$ & $\mathrm{Zn}$ & $\mathrm{Ti}$ \\
\hline $0.5 \% \mathrm{Si}$ & 0.504 & 0.101 & 0.006 & 0.001 & 0.001 & $<0.001$ & 0.004 & 0.005 \\
$1.0 \% \mathrm{Si}$ & 0.927 & 0.100 & 0.006 & 0.001 & 0.001 & $<0.001$ & 0.004 & 0.005 \\
$1.4 \% \mathrm{Si}$ & 1.40 & 0.098 & 0.006 & 0.001 & 0.001 & $<0.001$ & 0.004 & 0.005 \\
$5 \% \mathrm{Si}$ & 5.00 & 0.066 & 0.006 & 0.001 & 0.001 & $<0.001$ & 0.003 & 0.005 \\
$10 \% \mathrm{Si}$ & 10.06 & 0.074 & 0.007 & 0.002 & 0.001 & $<0.001$ & 0.004 & 0.006 \\
\hline
\end{tabular}

\section{2 評価項目, 測定条件}

\subsection{1 熱伝導率測定}

熱伝導率は熱拡散率と比熱, 密度の積から算出した。熱拡 散率と比熱はアドバンス理工製熱定数測定装置 TC-7000を使 い,レーザーフラッシュ法で測定した。いずれの物性も測定温 度は室温 $(294 \sim 300 \mathrm{~K})$ とし, 同一の $\varphi 10 \times{ }^{t} 2 \mathrm{~mm}$ 試験片を使っ て測定した。熱拡散率は試料表面にパルスレーザーを照射し た時の裏面の非定常温度変化を赤外線検出器により測定し, 得られた規格化温度曲線をハーフタイム法により解析して熱 拡散率を解析した。熱拡散率測定時の試料表面にはカーボン スプレーで黒化処理を施した。パルス加熱用レーザーには波 長 $1.06 \mu \mathrm{m}$ ，パルス幅約 $0.5 \mathrm{~ms}$ の $\mathrm{Nd}$ ガラスレーザーを使った。 比熱測定では試料およびサファイアともにグラッシーカーボ ンを受光板としてシリコーングリースを介して表面に貼り付 けて測定に供した。サファイアを標準試料として予めパル久 レーザーの熱量を校正しておき，試料にパルスレーザーを照 射した時の試料裏面の入熱に伴う温度上昇を $\varphi 0.1 \mathrm{~mm}$ の $\mathrm{R}$ 熱 電対で計測して求め, 入熱量を温度上昇で除した值から受光 板とグリースの比熱の寄与を差し引いて比熱を算出した。熱 拡散率と比熱はそれぞれ3 回繰り返し測定し, その平均值を 使って熱伝導率を算出した。密度は試験片の寸法打よび重量 を測定して求めた。試験片の厚さと直径はマイクロメータで5 点測定し，その平均值を使い密度を算出した。重量は電子天 秤で1 回測定した。供試材の密度は $2.64 \sim 2.68 \mathrm{~g} / \mathrm{cm}^{3}$ であった。

\subsection{2 電気比抵抗測定}

測定方法は直流四端子法とし, $3 \times 3 \times{ }^{L} 100 \mathrm{~mm}$ に切り出し た試験片の両端に純ニッケルの電流掞よび電圧リード線をス ポット溶接し，アドバンス理工製電気抵抗測定装置TER2000 RH/Lを使って室温（298 K）と液体窒素中（77 K）での電気 抵抗を測定した。試験片のサイズファクタは密度質量法 ${ }^{8)}$ 使った。電気比抵抗 $\rho_{\mathrm{D}}$ は電気抵抗と密度質量法サイズファク 夕の積より算出した。

一般的に, 多元希薄固溶体の温度 $T$ での比抵抗 $\rho^{\mathrm{SS}}(T)$ は次 式で表される。

$$
\rho^{\mathrm{SS}}(T)=\rho^{\mathrm{PURE}}(T)+\sum C^{i} \Delta \rho^{i}
$$

ここで $\rho^{\text {PURE }}(T)$ は理想的に純粋な溶媒金属の温度 $T$ での $\rho$, 添 字 $i$ は溶質種, $C$ は溶質濃度, $\Delta \rho$ は溶質単位濃度当たりの $\rho$ へ の寄与である。小松ら ${ }^{8)}$ は (2) 式から $300 \mathrm{~K}$ と $77 \mathrm{~K}$ での抵抗 比 $R\left(=\rho_{300} / \rho_{77}\right)$ を使い,

$$
\rho_{77}^{\mathrm{SS}}=\left(\rho_{300}^{\mathrm{PURE}}-\rho_{77}^{\mathrm{PURE}}\right) /(R-1)
$$

を誘導した。ここで $\rho$ SS は固溶体合金の比抵抗， $\rho^{\mathrm{PURE}}$ は純金 属の比抵抗である。小松らは実測した $R$ と $\rho$ から求めた経験式

$$
\begin{gathered}
\rho_{77}=\alpha /(R-1)+\beta \\
\rho_{300}=\alpha^{\prime} R /(R-1)+\beta^{\prime}
\end{gathered}
$$

をマティーセン則経験式と呼び，そのプロットはマティーセ ンプロットと呼んで測定誤差の検出に使っている。晶出ある いは析出する第二相の $\rho$ が固溶体に比較して十分に高い場 合，実測したRからマティーセン則経験式を使って逆算した 比抵抗 $\rho_{\mathrm{M}}$ は，第二相の影響を受けない基質固溶体だけの $\rho$ と

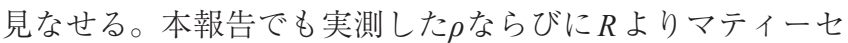
ン則経験式を使い， $\rho_{\mathrm{M}}$ を算出した。

\section{3. 実験結果と考察}

\section{3. $1 \mathrm{Al}-\mathrm{Si}$ 二元合金の比抵抗の溶質濃度依存性}

Fig. 1 に Si含有量 $C^{\mathrm{Si}}$ と溶体化処理後の $77 \mathrm{~K}$ での電気比抵抗 $\rho_{\mathrm{D} 77}$ との関係を示す。 $\rho_{\mathrm{D} 77}$ は $1.4 \%$ までは $C^{\mathrm{Si}}$ に対して直線的に 増加し, $843 \mathrm{~K} て ゙ の$ 溶体化処理で添加されたSiが全量固溶し たと考えられる。Fig. 2 に示す 298 Kでの電気比抵抗 $\rho_{\mathrm{D} 298}$ でも 同様の傾向が見られた。

Fig. 1 と2それぞれについて $1.4 \%$ 以下までの $C^{\mathrm{Si}}-\rho_{\mathrm{D}}$ 直線を 回帰して次式を得た。

$$
\begin{aligned}
& \rho_{\mathrm{D} 77} / \mathrm{n} \Omega \mathrm{m}=3.86+5.65 C^{\mathrm{Si}} / \mathrm{mass} \% \\
& \rho_{\mathrm{D} 298} / \mathrm{n} \Omega \mathrm{m}=29.1+5.71 C^{\mathrm{Si}} / \mathrm{mass} \%
\end{aligned}
$$

求めた $C^{\mathrm{Si}}-\rho_{\mathrm{D}}$ 直線の勾配, すなわち $\mathrm{Al}$ 中に固溶した $\mathrm{Si}$ の $\rho$ へ の寄与 $\Delta \rho^{\mathrm{Si}}$ を Table 2 に示す。比較のため小松らの集録泉の値 と比較したところ, 両温度とも本報の測定值の方が収録の值 よりも小さくなった。また, Al-Si系ではマティーセン則から のずれ（Deviation from Matthiessen's rule：DMR）があること が報告されて扔り，小松 ${ }^{10)} ら の$ 取り扱いによればその DMR は正とされている。本報で得られた $\Delta \rho \rho^{\mathrm{Si}} 298 \mathrm{~K}$ が $77 \mathrm{~K}$ の値 を上回り，正のDMRを示した。

$\mathrm{Si}$ 添加量 $5 \%$ 以上の試料では， $\rho_{\mathrm{D} 77}$ は $1.4 \%$ 以下とは異なる 勾配で増加する傾向を示した。この増加は, 最大平衡固溶 度以上に添加されて晶出あるいは析出した単体 $\mathrm{Si}$ による通電 断面積の過大評価が原因と考元られる。Si添加量 $1.4 \%$ 以下の $\rho_{\mathrm{D} 77}-1 /(R-1)$ プロット㧍よび $\rho_{\mathrm{D} 298}-R /(R-1)$ プロットより, $\mathrm{Si}$ 完全固溶状態のマティーセン則経験式を導出した。

$$
\begin{gathered}
\rho_{\mathrm{M} 77} / \mathrm{n} \Omega \mathrm{m}=25.36 /(R-1)-0.01648 \\
\rho_{\mathrm{M} 298} / \mathrm{n} \Omega \mathrm{m}=25.67 R /(R-1)-0.4821
\end{gathered}
$$

DMRがある系ではマティーセン則経験式にも影響が現れ， 


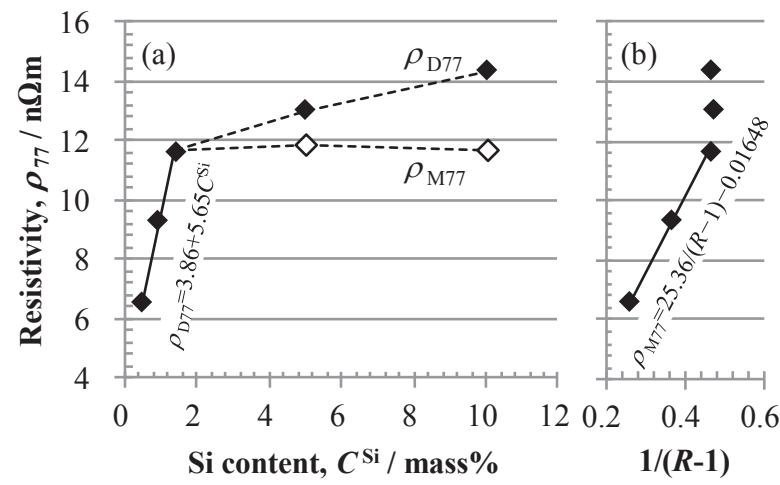

Fig. 1 (a) Relation between Si content and resistivity at 77 $\mathrm{K}$, and (b) Matthiessen plots according to equation (4). $\rho_{\mathrm{M} 77}$ calculated from the resistivity ratio $R\left(=\rho_{298} / \rho_{77}\right)$ using Matthiessen empirical relation in completely dissolved state, equation (5).

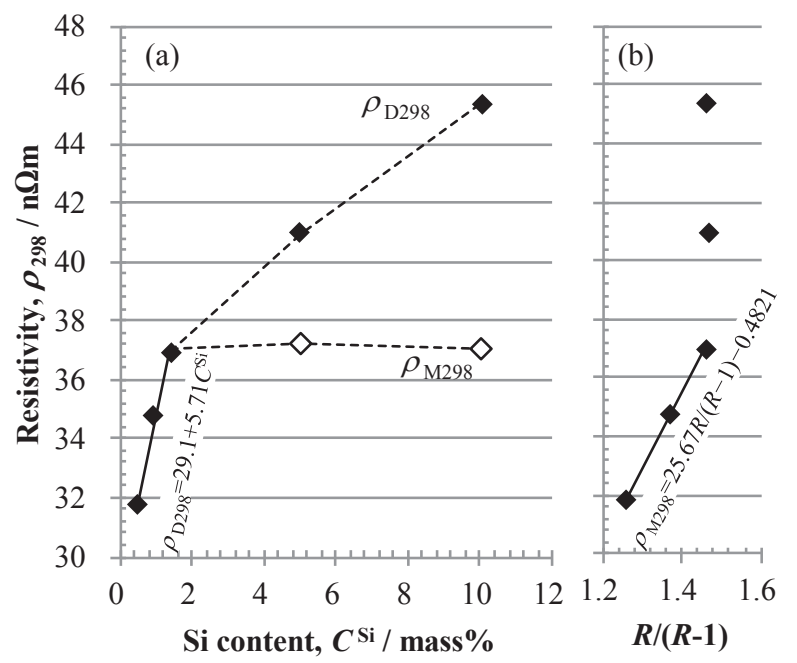

Fig. 2 (a) Relation between Si content and resistivity at 298K, and (b) Matthiessen plots according to equation (4').

Table 2 Contributions of solute silicon in aluminum to resistivity, $\Delta \rho$ Si and temperature of $\rho$ measurement, $T$.

\begin{tabular}{l|l|l}
\hline \hline \multirow{2}{*}{ Investigators } & \multicolumn{2}{|c}{$\Delta \rho / \mathrm{n} \Omega \mathrm{m} \cdot{\text { mass } \%{ }^{-1}}^{-1}$} \\
\cline { 2 - 3 } & $77 \mathrm{~K}$ & $298 \mathrm{~K}$ or $300 \mathrm{~K}$ \\
\hline Present work & 5.65 & 5.71 (at $298 \mathrm{~K}$ ) \\
Komatsu et al. & 6.30 & 6.68 (at $300 \mathrm{~K})$ \\
\hline
\end{tabular}

その勾配 ように二温度での $\Delta \rho$ を測定している場合，それらを使って 補正が可能だが，本報ではDMRが小さい事と $\rho$ 測定精度を勘 案して補正はしないこととした。(6) 㧍よび (6') 式より $5 \% \mathrm{Si}$ および $10 \% \mathrm{Si}$ の $\rho_{\mathrm{M} 77}$ を計算すると，それぞれ $11.8 \mathrm{n} \Omega \mathrm{m}, 11.7$ $\mathrm{n} \Omega \mathrm{m}$ と $1.4 \%$ の実測值 $11.7 \mathrm{n} \Omega \mathrm{m}$ とほぼ一致した。ここで, 各 試料の $\rho_{\mathrm{M} 77}$ を溶質が $843 \mathrm{~K}$ の平衡固溶度まで固溶した状態の $\rho$ 計算値 $\left(\rho_{\text {cal.77 }}\right)$ と比較するため Fig. 3 に $\rho_{\text {M } 77}$ と $\rho_{\text {cal.77 }}$ を示す。 $\mathrm{Si}$ の溶質濃度は, $1.4 \% \mathrm{Si}$ 以下の試料は $\mathrm{Si}$ 全量固溶していると して Table 1の分析值を，5\%Si以上は（1）式から計算した 843 $\mathrm{K}$ での平衡固溶度 1.55 mass\%を, $\mathrm{Fe}$ は $843 \mathrm{~K}$ での平衡固溶度

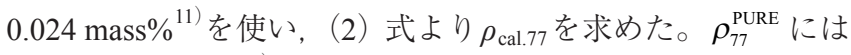
Desai らの推奨值 ${ }^{12}$ を $77 \mathrm{~K}$ に内挿して得た $2.20 \mathrm{n} \Omega \mathrm{m}$ を, $\mathrm{Si}$ と $\mathrm{Fe}$ の $\Delta \rho$ はそれぞれ集録の值 ${ }^{9)} 6.30 \mathrm{n} \Omega \mathrm{m} \cdot \mathrm{mass}^{2} \%^{-1}, 38.4 \mathrm{n} \Omega \mathrm{m}$.

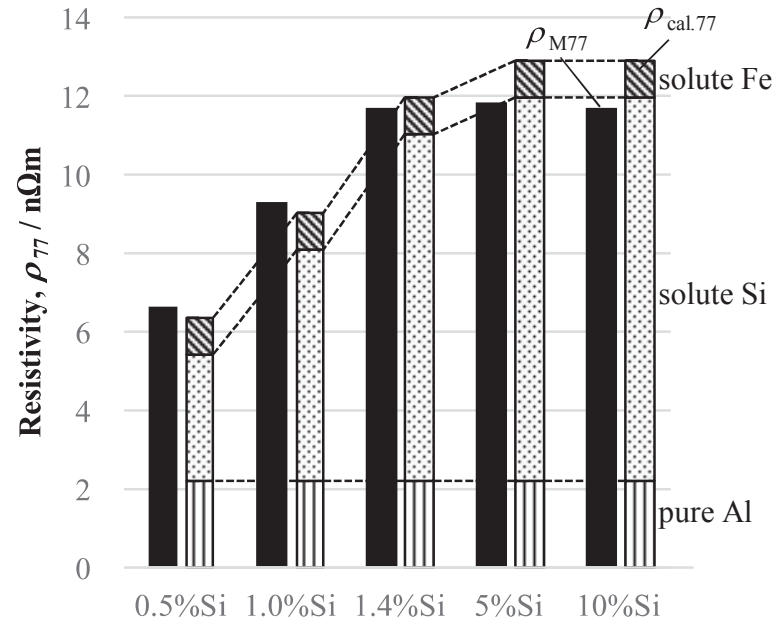

Fig. 3 Comparisons of $\rho_{\mathrm{M} 77}$ and calculated resistivity $\left(\rho_{\text {cal.77 }}\right)$ in as quenched state of Al-Si alloys. $\rho_{\text {cal.77 }}$ were calculated from equilibrium solubility of each solute in binary system at $843 \mathrm{~K}$.

mass $\%^{-1}$ を使った。 $1.4 \% \mathrm{Si}$ 以下の試料では $\rho_{\mathrm{M} 77}$ は $\rho_{\text {cal.77 }}$ とほぼ 一致し， $5 \% \mathrm{Si}$ 以上は $\rho_{\mathrm{M} 77}$ の方が $10 \%$ 前後低くなった。 $\mathrm{Al}-\mathrm{Fe}-$ $\mathrm{Si}$ 三元系では Al-Fe-Si系化合物が形成され, $\mathrm{Si}$ の平衡固溶度 が減少する ${ }^{13)}$ 。さらに, $1.4 \% \mathrm{Si}$ も $\rho_{\mathrm{M} 77}$ が $\rho_{\text {cal.77 }}$ をずかに下 回っており,ごく少量のSiが未固溶のまま残留していた可能 性を示唆している。もしこの仮説が正しいならば, Table 2の $\Delta \rho^{\mathrm{Si}}$ が集録の值を下回ったことも説明できる。

\section{2 晶析出の熱伝導率および電気伝導度への影響}

熱伝導率入に対する $C^{\mathrm{Si}}$ の影響を Fig. 4 に示す。一般的な金 属材料では熱伝導に扔ける主要な熱のキャリアは電気伝導と 同じく自由電子であることが知られている。したがって, גは $\rho$ の逆数である電気伝導度 $\sigma$ と相関を持ち, $\lambda$ は $\rho$ と増減の傾

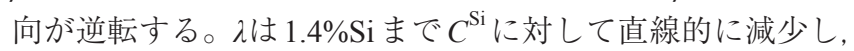
$5 \% \mathrm{Si}$ 以上では $1.4 \% \mathrm{Si}$ 以下とは異なる勾配で減少した。 $\lambda$ の逆 数 $\lambda^{-1}$ でも $\rho$ と同様にマティーセン則が成立することが知られ ており，(2）式と同様の整理ができるはずである。そこで, $C^{\mathrm{Si}}-\lambda^{-1}$ プロットから基質固溶体中の固溶 $\mathrm{Si}$ の単位溶質濃度 あたりの熱伝導率の逆数への寄与を求めてみる。Fig. 5 の $C^{\mathrm{Si}}$ $-\lambda^{-1}$ プロットに示す通り, やはり $1.4 \% \mathrm{Si}$ 以下のプロットは 1 本の直線上に乗り，それらを直線回帰して次式を得た。

$$
\lambda^{-1} / \mathrm{W}^{-1} \mathrm{~m} \cdot \mathrm{K}=4.70 \times 10^{-3}+0.856 \times 10^{-3} \mathrm{C}^{\mathrm{Si}} / \mathrm{mass} \%
$$

上述の通り, 純金属固体では熱伝導は電気伝導とキャリア が同じであることからヴィーデマンーフランツ則が成り立 ち, $\lambda$ と電気伝導度 $\sigma(=1 / \rho)$ の関係は

$$
\lambda=L T \sigma
$$

と表されることが知られている。（8）式の係数 $L$ はローレン ツ数と呼ばれ, 理論值は $2.445 \times 10^{-8} \mathrm{~W} \Omega \mathrm{K}^{-2}$ である。室温での $\lambda$ とのの值を Fig. 6 にプロットした。図中の破線は純 $\mathrm{Al}$ の 300 $\mathrm{K}$ のとのの推奨值 ${ }^{12)}{ }^{14)}$ ，それぞれ $237 \mathrm{~W}(\mathrm{~m} \cdot \mathrm{K})^{-1}, 36.6 \times 10^{8}$ $(\Omega \mathrm{m})^{-1}$ を使って算出した $L=2.16 \times 10^{-8} \mathrm{~W} \Omega \mathrm{K}^{-2}$ の直線であ る。0.5 1.4\% Si は一つの直線上にあり, この $\lambda-\sigma$ 直線を回帰 して次式を得た。

$$
\lambda=5.83 \times 10^{-6} \sigma+12.5
$$


一方で， $5 \% \mathrm{Si}$ と 10\% $\mathrm{Si}$ は（9）式から乘離した。 $\lambda$ とから算 出したLを Table 3 に示す。 $5 \% \mathrm{Si}$ 以上では $\mathrm{Si}$ 量の増加と共に $L$ が大きくなった。これは晶析出 $\mathrm{Si}$ による通電断面積の過大評

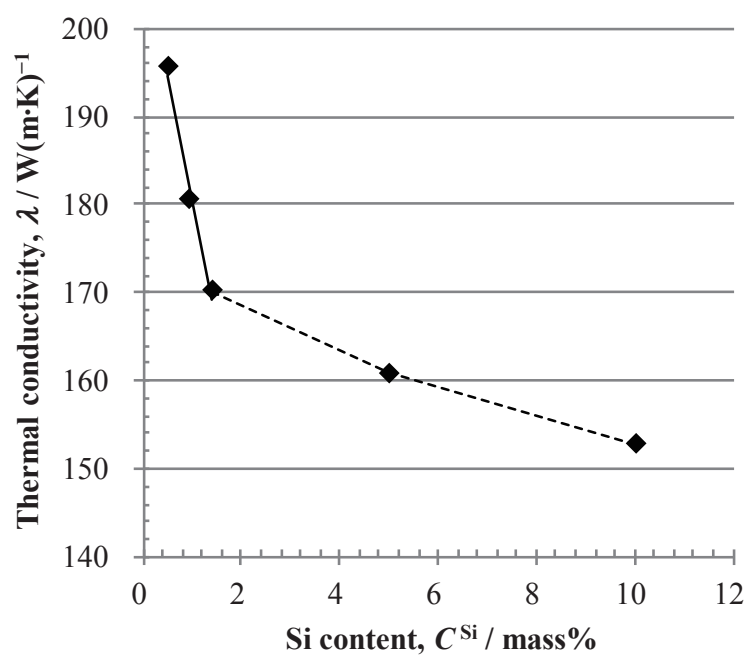

Fig. 4 Relation between Si content and thermal conductivity at room temperature $(294 \sim 300 \mathrm{~K})$.

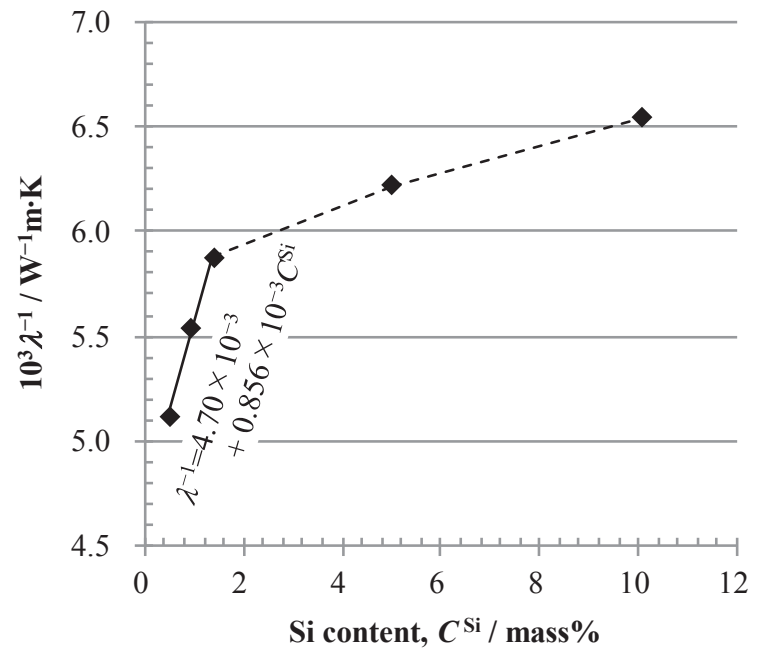

Fig. 5 Relation between Si content and reciprocal of thermal conductivity, $\lambda^{-1}$.

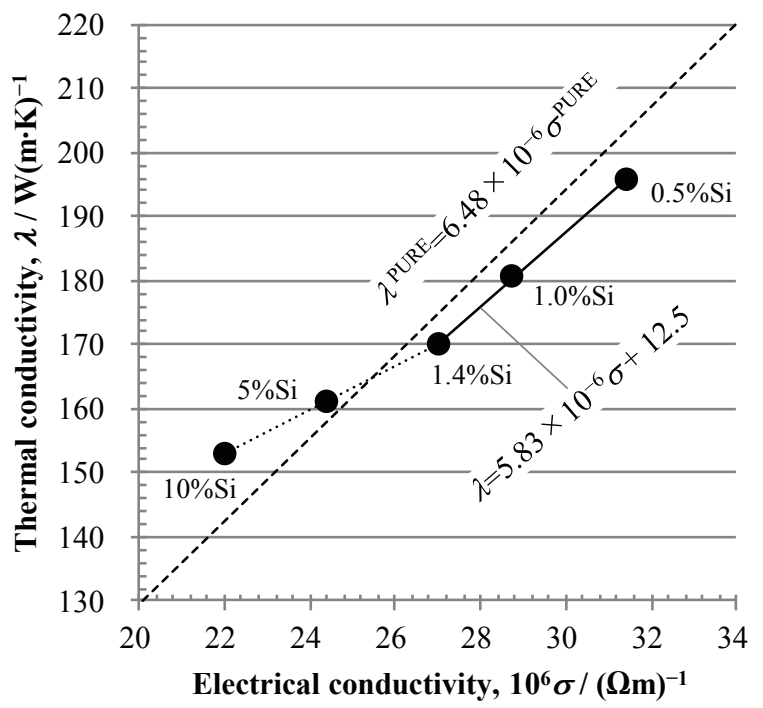

Fig. 6 Relation between electrical conductivity and thermal conductivity.
価の影響に加えて, ヴィーデマンーフランツ則が金属の自由 電子による電気伝導に対して構築された理論であることを踏 まえると, 半導体である単体 $\mathrm{Si}$ のへへの寄与の仕方が $\sigma$ とは異 なることを示唆している。

\section{3 複合則による晶析出 Si の体積分率の推定}

母相中に分散している球状の第二相粒子について，その体 積分率 $V_{2}$ が母相の体積分率 $V_{1}$ よりも十分に小さいと見なせ る時, 粒子分散型複合材料の熱伝導率 $\lambda$ や電気伝導度 $\sigma$ 等の物 性 $X$ はマクスウェルの式で表される ${ }^{15)}$ 。

$$
X=\frac{2 X_{1}+X_{2}+2 V_{2}\left(X_{2}-X_{1}\right)}{2 X_{1}+X_{2}-V_{2}\left(X_{2}-X_{1}\right)} X_{1}
$$

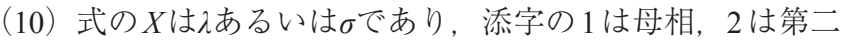
相を意味する。ここで（10）式を変形して，本報で測定した

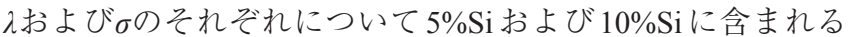
晶析出 $\mathrm{Si}$ 粒子の体積分率 $V_{\mathrm{Si}}$ を試算してみる。

（10）式の $X$ をとして Al-Si 合金に適用すると, $\lambda$ から求め た晶析出 $\mathrm{Si}$ 粒子の体積分率 $V_{\lambda-\mathrm{Si}}$ は次式で表される。なお，母 相は $\mathrm{Al}$ 基固溶体, 第二相粒子は晶析出 $\mathrm{Si}$ であることから, 式 中の添え字1，2はそれぞれ $\mathrm{Al}, \mathrm{Si}$ と書き換えた。添え字の無 いれは供試材の実測值である。

$$
V_{\lambda-\mathrm{Si}}=\frac{-\left(2 \lambda_{\mathrm{Al}}+\lambda_{\mathrm{Si}}\right)\left(\lambda_{\mathrm{Al}}-\lambda\right)}{\left(\lambda+2 \lambda_{\mathrm{Al}}\right)\left(\lambda_{\mathrm{Si}}-\lambda_{\mathrm{Al}}\right)}
$$

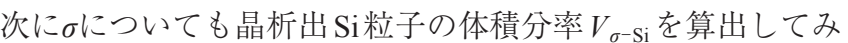
る。Si粒子の電気伝導度 $\sigma_{\mathrm{Si}}$ は大きく見積もっても $0.01(\Omega \mathrm{m})^{-1}$ であり，母相の電気伝導度 $\sigma_{\mathrm{Al}}$ と比べて極めて小さいため $\sigma_{\mathrm{Si}} \approx$ 0 とみなすことができる。この点を踏まえて（10）式を $\sigma$ に適 用すると， $V_{\sigma-\mathrm{Si}}$ は次式のように近似できる。(12) 式の添え字 も（11）式と同様であり, 添え字の無い $\sigma$ は供試材の実測值 を使った。

$$
V_{\sigma-\mathrm{Si}}=\frac{2\left(\sigma_{\mathrm{Al}}-\sigma\right)}{2 \sigma_{\mathrm{Al}}+\sigma}
$$

晶析出 $\mathrm{Si}$ 粒子の体積分率 $V_{\mathrm{Si}}$ の試算にあたり, $\mathrm{Si}$ 粒子の $\lambda_{\mathrm{Si}}$ は $138.5 \mathrm{~W}(\mathrm{~m} \cdot \mathrm{K})^{-1}$ とし ${ }^{16)}$ ，基質固溶体の $\lambda_{\mathrm{Al}}$ は $1.4 \% \mathrm{Si}$ の実測值 $170 \mathrm{~W}(\mathrm{~m} \cdot \mathrm{K})^{-1}$ を使い， $\sigma_{\mathrm{Al}}$ は $\rho_{\mathrm{M} 298}$ から算出した值を使用した。 $\lambda$ と $\sigma$ から算出した $V_{\mathrm{Si}}$ を Table 4 に示す。また, $\rho_{\mathrm{M} 298}$ を使って (5') 式より推定した $\mathrm{Si}$ 固溶量 $C_{\mathrm{Si}}^{\mathrm{SS}}$ を除いた全量が晶析出 $\mathrm{Si}$ 量 であると仮定して次式より求めた $V_{\text {sol-Si }}$ も Table 4 に併記した。

$$
V_{\mathrm{sol}-\mathrm{Si}}=\frac{\left(C_{\mathrm{Si}}^{\mathrm{Total}}-C_{\mathrm{Si}}^{\mathrm{SS}}\right) / D_{\mathrm{Si}}}{\left(100-C_{\mathrm{Si}}^{\mathrm{Total}}+C_{\mathrm{Si}}^{\mathrm{SS}}\right) / D_{\mathrm{Al}}+\left(C_{\mathrm{Si}}^{\mathrm{Total}}-C_{\mathrm{Si}}^{\mathrm{SS}}\right) / D_{\mathrm{Si}}}
$$

ここで $C_{\mathrm{Si}}^{\text {Total }}$ は Table 1 に示す各試料の $\mathrm{Si}$ 添加量, $D_{\mathrm{Si}}$ と $D_{\mathrm{Al}}$

Table 3 Lorenz numbers of Al-Si alloys.

\begin{tabular}{c|c}
\hline \hline specimen & Lorenz number $10^{8} \mathrm{~L} / \mathrm{W} \Omega \mathrm{K}^{-2}$ \\
\hline $0.5 \%$ & 2.09 \\
$1.0 \%$ & 2.11 \\
$1.4 \%$ & 2.11 \\
$5 \%$ & 2.21 \\
$10 \%$ & 2.33 \\
\hline
\end{tabular}


はSi粒子と基質固溶体の密度であり，それぞれ純金属の值で ある $2.328 \mathrm{~g} \cdot \mathrm{cm}^{-3}, 2.7 \mathrm{~g} \cdot \mathrm{cm}^{-3}$ とした ${ }^{17)} 。 V_{\sigma-\mathrm{Si}}$ は $V_{\text {sol-Si }}$ より約 30 ～ $50 \%$ 大きくなった。これは小松ら ${ }^{18)}$ が提唱する電流遮蔽領 域の影響で $V_{\sigma-\mathrm{Si}}$ が過大評価されたと考えられる。一方， $V_{\lambda-\mathrm{Si}}$ は $V_{\text {sol-Si }}$ の 5 7倍とさらに大きな乘離を示した。熱伝導も上 記電流遮蔽領域と同様に, 界面熱抵抗という形で熱のキャリ アが遮蔽される事象の考え方があるが，そのオーダーは $10^{-7}$ $\mathrm{W}^{-1} \mathrm{~m}^{2} \mathrm{~K}$ より小さいと言われている融。 $\mathrm{Si}$ 粒子と基質固溶体 間の界面熱抵抗を試算してみる。単純化のため Si 粒子と基質 固溶体を二層材料と仮定し，二層間の一方向の熱伝導での界 面熱抵抗を逆算すると $10^{-7} \sim 10^{-6} \mathrm{~W}^{-1} \mathrm{~m}^{2} \mathrm{~K}$ となり, 上記の数值 からはまだ 1 桁程度は大きく, 界面熱抵抗だけでは上記の説 明は難しい。

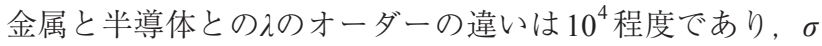
の $10^{7}$ 程度に比べると大幅に小さい。そのため基質固溶体中 に分散しているSi粒子の熱伝導への寄与は, 電気伝導とは異 なり無視できないと考えられる。この点は（11）式と（12） 式でも現れている。複合材料中の分散粒子サイズが熱のキャ リア，すなわち自由電子の平均自由行程に近づくと，界面で のキャリア散乱頻度が増加して分散粒子のגは低下するだろ う。また, $\mathrm{Si}$ 粒子中への $\mathrm{Al}$ 固溶量は非常に小さいと推定さ れ，自由電子や正孔だけではなくフォノンも熱のキャリアと して一定の割合を占めている可能性が高い。フォノン伝導に 対するサイズ効果は，粒子サイズがナノスケールになると顕 著になるという計算結果が報告されている ${ }^{20)}$ 。供試材のミク 口組織を Fig. 7 に示す。Si粒子サイズは大きなものでは数十 $\mu \mathrm{m}$ だが, 厚さ数 $\mu \mathrm{m}$ 程度の針状の粒子も散見され，一部の微 細な $\mathrm{Si}$ 粒子では $\lambda_{\mathrm{Si}}$ 降下が起こり得る可能性がある。ただし, Fig. 7 からもわかる通り，5\%㧍よび $10 \% \mathrm{Si}$ では Si粒子の体積 分率は数\%〜十数\%と考えられ，マクスウェルの式の前提で ある第二相粒子の体積分率が母相よりも十分に小さいという 条件を満たしていない。そのため定量的な議論ができていな い可能性がある。さらに詳細に考察するためには粒子の体積 分率や形状などを考慮して複合則の式を検討する必要がある が,この点については今後の課題としたい。

以上のことから，本報の測定結果にマクスウェルの式が適

Table 4 Comparisons of volume fraction of Si particles calculated from $\lambda, \sigma$ and solute Si concentration calculated from $\rho_{\mathrm{M}}, V_{\lambda-\mathrm{Si}}, V_{\sigma-\mathrm{Si}}$ and $V_{\text {sol-Si }}$, respectively.

\begin{tabular}{c|c|c|c|c}
\hline \hline \multirow{2}{*}{ Specimen } & \multirow{2}{*}{$\begin{array}{c}\text { Solute Si } \\
\text { SS }\end{array}$} & \multicolumn{3}{|c}{ Volume fraction / vol. $\%$} \\
\cline { 3 - 5 } & $C_{\mathrm{Si}} /$ mass $\%$ & $V_{\lambda-\mathrm{Si}}$ & $V_{\sigma-\mathrm{Si}}$ & $V_{\text {sol-Si }}$ \\
\hline $5 \% \mathrm{Si}$ & 1.41 & $28 \%$ & $6.3 \%$ & $4.1 \%$ \\
$10 \% \mathrm{Si}$ & 1.39 & $53 \%$ & $13 \%$ & $9.9 \%$ \\
\hline
\end{tabular}

(a) $5 \% \mathrm{Si}$

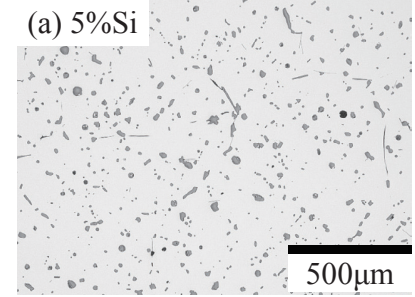

(b) $10 \% \mathrm{Si}$

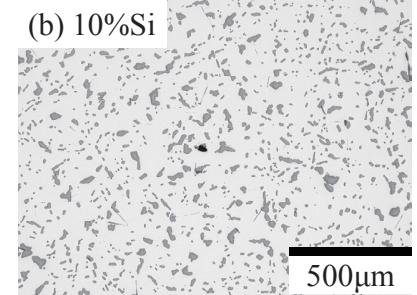

用できると仮定して解析すると， $V_{\lambda-\mathrm{Si}}$ が $V_{\sigma-\mathrm{Si}}$ に比べて $V_{\mathrm{sol}-\mathrm{Si}}$ と 大きな乘離を示したことは界面熱抵抗と微細 $\mathrm{Si}$ 粒子での $\lambda_{\mathrm{Si}}$ 降下が原因とすれば，定性的ではあるが理解できる。

\section{4. 結言}

（1）溶体化処理したAl-Si 合金の電気比抵抗 $\rho$ を測定し，ア

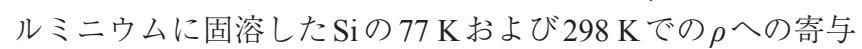
として，それぞれ $\Delta \rho_{77}{ }^{\mathrm{Si}}=5.65 \mathrm{n} \Omega \mathrm{m} \cdot \mathrm{mass}^{-1}{ }^{-1}, \Delta \rho_{298}{ }^{\mathrm{Si}}=5.71$ $\mathrm{n} \Omega \mathrm{m} \cdot \mathrm{mass}^{-1}{ }^{-1}$ が得られた。

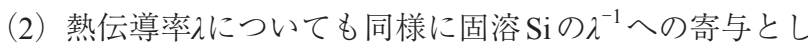
て, $0.856 \times 10^{-3} \mathrm{~W}^{-1} \mathrm{~m} \cdot \mathrm{K} \cdot \mathrm{mass}^{-1}{ }^{-1}$ が得られた。

（3）電気比抵抗と熱伝導率は $\mathrm{Si}$ のほぼ全量が固溶している 1.4 mass $\% S i$ まではヴィーデマン・フランツ則に従ったが， 5 mass $\% \mathrm{Si}$ と $10 \mathrm{mass} \% \mathrm{Si}$ は晶析出 $\mathrm{Si}$ 粒子の影響で $1.4 \mathrm{mass} \% \mathrm{Si}$ 以 下とは異なる傾向を示した。

（4）マクスウェルの式を使って熱伝導率および電気比抵抗 の実測值から計算した $\mathrm{Si}$ 粒子の体積分率 $V_{\lambda-\mathrm{Si}}$ と $V_{\sigma-\mathrm{Si}}$ は, いず れもマティーセン則経験式を使って求めた $\rho_{\mathrm{M}}$ を基に算出し た $V_{\mathrm{sol}-\mathrm{Si}}$ より大きくなった。 $V_{\sigma-\mathrm{Si}}$ の乘離については晶析出粒子 のキャリア遮蔽効果の寄与, $V_{\lambda-\mathrm{Si}}$ の乘離はそれに微細 $\mathrm{Si}$ 粒子 界面でのフォノン散乱の寄与が加わったものと仮定すると, 測定結果が無理なく説明できる。

\section{参 考 文 献}

1) 大中逸雄：鋳造工学, 87 (2015), 265-286.

2) 堀川 宏：軽金属, 58 (2008), 259-274.

3）例えば, 小松伸也, 池田勝彦, 筑田昌宏, 小林紘二郎：軽金属, 41 (1991)，510-514.

4) 貞富信裕, 濱本直也, 西郷恒和, 山下 治 : 粉体および粉末治 金, 49 (2002)，793-798.

5) R.Brandt and G.Neuer: Int. J. Thermophys., 28 (2007), 1429-1446.

6) 北岡山治：軽金属, 61 (2011), 485-503.

7) J.L. Murray and A.J. McAlister: Bull. Alloy Phase Diagrams, 5 (1984), 74-84.

8）小松伸也，藤川辰一郎：軽金属，47 (1997)，170-181，396-406

9) 小松伸也, 村松俊樹：軽金属, 50 (2000), 518-526.

10) 小松伸也, 池田勝彦, 松尾 守, 村松俊樹：軽金属, 41 (1991), 465-470.

11) 西尾通卓, 那須三郎, 村上陽太郎：日本金属学会誌, 34 (1970), 1173-1177.

12) P.D. Desai, H.M. James, and C.Y. Ho: J. Phys. Chem. Ref. Data, 13 (1984), 1131-1172.

13) G. Ghosh: Landolt-Börnstein New series IV/11A2 Light Metal Systems. Part 2: Selected Systems from Al-Cu-Fe to Al-Fe-Ti, Springer, (2005), 359-408.

14) Y. S. Touloukian, R. W. Powell, C. Y. Ho and P. G. Klemens: Thermophysical properties of matter - the TPRC data series. Volume 1. Thermal conductivity - metallic elements and alloys, IFI/Plenum, (1970), 1-9.

15）杉本孝一, 長村光造, 山根壽己, 牧 正志, 菊池潮美, 落合庄 治郎，村上陽太郎：材料組織学，朝倉書店，(1991）, 161-178.

16）日本金属学会編：“金属データブック”, 改訂4版, 丸善, (2004), 13.

17) 日本金属学会編：“金属データブック”, 改訂4版, 丸善, (2004), 10.

18）小松伸也, 池田勝彦, 筑田昌宏, 小林紘二郎：軽金属, 41 (1991), 510-514.

19) T. Baba, N. Taketoshi and T. Yagi: Jpn. J. Appl. Phys., 50 (2011), 11RA01.

20) 塩見淳一郎：伝熱, $\mathbf{5 0}$ (2011), 21-28.

Fig. 7 Microstructures of Al-Si alloys. 